\title{
Studies on the control of gluconeogenesis in sheep : effect of propionate, casein and butyrate infusions
}

\author{
BY G. J. JUDSON* AND R. A. LENG \\ Department of Biochemistry and Nutrition, School of Rural Science, \\ University of New England, Armidale, New South Wales, 235 I, Australia
}

(Received I7 December 1971 - Accepted 29 June 1972)

\begin{abstract}
I. Short-term effects of infusions of propionate, amino acids and butyrate on gluconeogenesis, as indicated by changes in the irreversible loss of plasma glucose, synthesis of glucose from ruminal propionate or fixation of blood bicarbonate into glucose have been examined in sheep given their daily ration in twenty-four equal portions at hourly intervals.

2. Sheep received intravenous infusions of $\left[6-{ }^{3} \mathrm{H}\right]$ glucose usually in combination with [U-14 C]glucose or $\mathrm{NaH}^{14} \mathrm{CO}_{3}$ or with intraruminal infusions of $\left[2-{ }^{14} \mathrm{C}\right]$ propionate. Substrates were infused over a $3-7 \mathrm{~h}$ period and followed estimates of pre-infusion linetic measurements.

3. It was demonstrated that intraruminal and intramesenteric vein infusions of sodium propionate and intra-abomasal infusions of casein hydrolysate stimulated gluconeogenesis. Glucose synthesis showed a linear response to the infusion of these substrates, which varied from $0.35-6.35 \mathrm{mmol}$ propionate $/ \mathrm{min}$ and $50-160 \mathrm{mg}$ casein $/ \mathrm{min}$.

4. The increment in the measured production rate of propionate in the rumen was consistently less than the rate of addition of propionate to the rumen.

5. Intramesenteric vein infusions of sodium butyrate at successive rates of 0.25 and $0.50 \mathrm{mmol} / \mathrm{min}$ produced only an initial transient increase in plasma glucose production. Since the rate of glucose synthesis from ruminal propionate was not altered, it was suggested that butyrate initiated glycogen mobilization.
\end{abstract}

In ruminants, gluconeogenesis increases during pregnancy (Bergman, 1963; Ford, r963; Steel \& Leng, r968) and lactation (Annison \& Linzell, r964; Bergman \& Hogue, I967) and decreases during starvation (Annison \& White, 196r; Kronfeld \& Simesen, 1961; Leng, 1970a). This apparent adaptation of gluconeogenesis to different physiological conditions suggests that ruminants possess well-controlled mechanisms for the regulation of this process. Recent evidence indicates that the quantity and quality of the diet is an important factor controlling gluconeogenesis in sheep (Ford, 1965; Judson, Anderson, Luick \& Leng, I968; Judson \& Leng, I968).

The present experiments were designed to measure short-term effects of infusions of propionate, amino acids and butyrate on the rate of gluconeogenesis in sheep given a roughage diet. The rate of incorporation of carbon-I4 from ruminal propionate or blood bicarbonate into plasma glucose was used as an index of gluconeogenesis.

\section{EXPERIMENTAL}

\section{Animals and diet}

Thirteen Merino ewes or wethers, aged $3-5$ years, were housed in single pens. They were given a daily ration of $800 \mathrm{~g}$ lucerne chaff having a digestible energy and crude protein content of about $7.95 \mathrm{MJ}$ and $97 \mathrm{~g}$ respectively (Judson \& Leng, I973).

* Present address: Division of Animal Science, Institute of Medical and Veterinary Science, Frome Road, Adelaide, South Australia, 5000, Australia. 
Eleven sheep were fitted with ruminal cannulas and two with abomasal cannulas. Five of the sheep with ruminal cannulas were each prepared with an indwelling nylon catheter in a mesenteric vein (Moodie, Walker \& Hutton, 1963). The catheters were flushed daily with physiological saline and refilled with heparinized saline (6o i.u./ml). Care was taken to minimize the entry of heparin into the animal by withdrawing the residual heparinized saline before flushing with saline.

All surgical operations were performed at least 4 weeks before the start of the experiment.

\section{Experimental procedures}

Sheep were given their daily ration of $800 \mathrm{~g}$ lucerne chaff in twenty-four equal portions at hourly intervals, and were also given intravenous infusions of [U-14 C]glucose, $\left[6-{ }^{3} \mathrm{H}\right]$ glucose and $\mathrm{NaH}^{14} \mathrm{CO}_{3}$ and intraruminal infusions of $\left[2^{-14} \mathrm{C}\right]$ propionate as previously described (Judson \& Leng, I973).

Sodium propionate, sodium butyrate or enzymic-hydrolysed casein (Sigma Chemical Company, St Louis, Missouri, USA) were administered to sheep after a period in which pre-infusion values were obtained for the concentration and specific radioactivity (SR) of metabolites isolated from blood and ruminal fluid as described for glucose infusions (Judson \& Leng, I973). Sodium propionate and butyrate were of analytical reagent grade and only traces of other volatile fatty acids (VFA) were detected by gas-liquid chromatography. These salts were dissolved in distilled water and infused intravenously through the mesenteric vein catheter or intraruminally (for propionate solutions) at rates of $0.2-0.6 \mathrm{ml} / \mathrm{min}$. Physiological saline was infused at $0.2 \mathrm{ml} / \mathrm{min}$ into the intramesenteric vein catheter during the 'control' period of the experiment. When sodium propionate was infused intraruminally during infusions of $\left[2-{ }^{14} \mathrm{C}\right]$ propionate, the separate leads carrying these substrates to the animal were joined by a Y-piece to the infusion probe within the rumen so that the infused propionate and isotope were mixed before their distribution within the rumen.

\section{Chemical analysis and determination of radioactivity}

Methods used for the determination of glucose, lactate and urea concentrations in plasma, total concentrations of VFA and molar percentages of individual VFA in ruminal fluid and the isolation of propionate from ruminal fluid, glucose from plasma and bicarbonate from blood and their assay for radioactivity have been given previously (Judson \& Leng, 1973). Two blood samples of equal volume, taken at 20-30 min intervals immediately before or during the completion of the propionate and butyrate infusions, were bulked and the VFA isolated as described by Annison \& Lindsay ( I96I) for chromatography of individual VFA. Plasma $\alpha$-amino nitrogen concentrations were determined by the colorimetric method of Rosen (I957) and plasma $\mathrm{D}(-)-\beta$-hydroxybutyrate by the enzyme method of Williamson, Mellanby $\&$ Krebs (1962). 


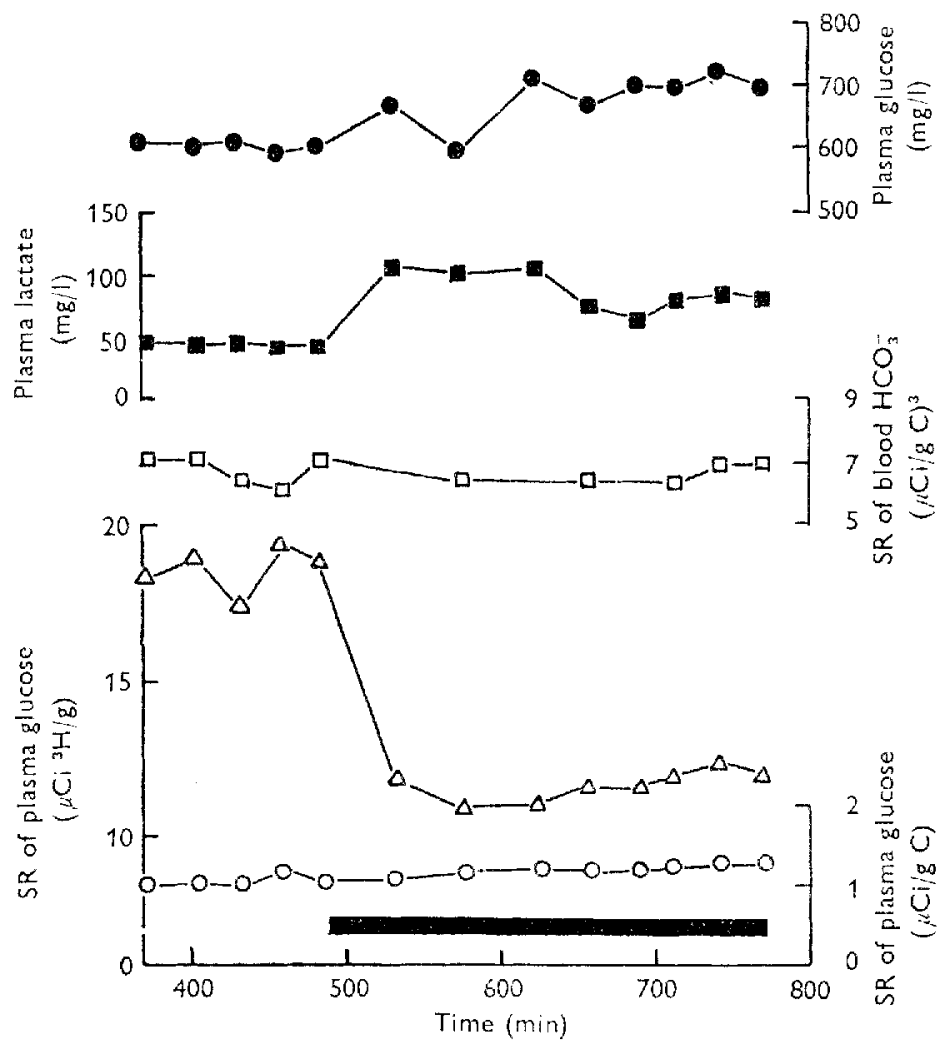

Fig. I. Effect of an intravenous infusion of propionate on the specific radioactivity (SR) values of plasma glucose and blood bicarbonate and the plasma concentrations of glucose and lactate in sheep no. 140 during a constant infusion of a mixture of $\left[6-{ }^{3} \mathrm{H}\right]$ glucose and $\mathrm{NaH}^{14} \mathrm{CO}_{3}$. $O$, SR of glucose $(\mu \mathrm{Ci} / \mathrm{g} \mathrm{C}) ; \triangle$, SR of glucose $\left(\mu \mathrm{Ci}{ }^{3} \mathrm{H} / \mathrm{g}\right) ; \square$, SR of blood bicarbonate; $\boldsymbol{\varphi}$, concentration of glucose; $\mathbf{E}$, concentration of lactate. The SR of metabolite was adjusted to an infusion rate of $\mathrm{I} \mu \mathrm{Ci}$ isotope/min. Sodium propionate was infused into a mesenteric vein at $0.99 \mathrm{mmol} / \mathrm{min}$ between the 48 oth and 77 oth min (horizontal bar) of the infusion of isotopes.

\section{Calculations}

The irreversible loss of metabolite and the net rate of synthesis of glucose carbon from ruminal propionate or blood bicarbonate were calculated as previously described (Judson \& Leng, I973).

\section{RESULTS}

Effect of propionate infusions on the irreversible loss of plasma ghcose

Propionate varying between 0.35 and $6.35 \mathrm{mmol} / \mathrm{min}$ was infused into the rumen of five sheep at a single rate or at two different successive rates of equal duration. A further three sheep were given intravenous infusions of propionate through the mesenteric vein at 0.99 or $1.92 \mathrm{mmol} / \mathrm{min}$. The irreversible loss of plasma glucose before and during propionate infusions was measured by using a constant infusion of $\left[\mathrm{U}-14^{14} \mathrm{C}\right]$ glucose or $\left[6-{ }^{3} \mathrm{H}\right]$ glucose, or both, lasting $13^{-14} \mathrm{~h}$. Propionate was infused over the last 5 or $6 \mathrm{~h}$ of the isotope infusion. Results from typical experiments in 

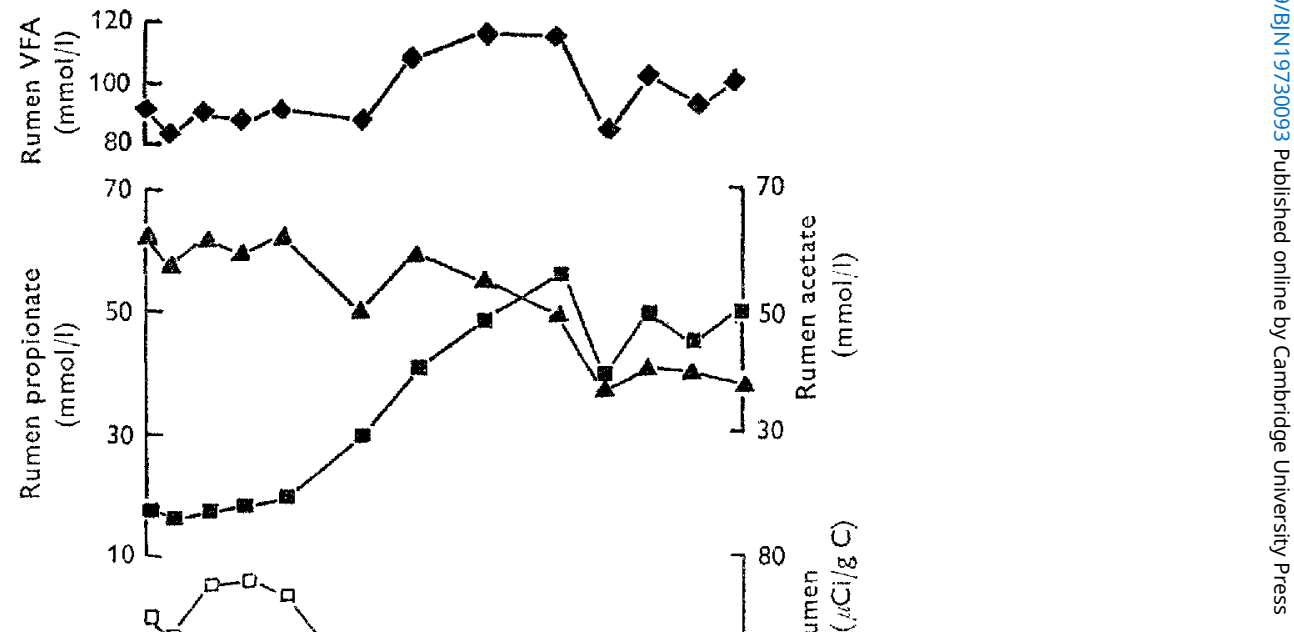

Fig. 2. Effect of an intraruminal infusion of propionate on the specific radioactivity (SR) of plasma glucose and ruminal propionate, and the concentrations of plasma glucose and of acetate, propionate and total VFA in ruminal fluid of sheep 175 during an intravenous infusion of $\left[6-{ }^{3} \mathrm{H}\right]$ glucose and an intraruminal infusion of $\left[2-{ }^{14} \mathrm{C}\right]$ propionate, administered simultaneously. $O$, SR of glucose $(\mu \mathrm{Ci} / \mathrm{g} \mathrm{C}) ; \Delta, \mathrm{SR}$ of glucose $\left(\mu \mathrm{Ci}^{3} \mathrm{H} / \mathrm{g}\right) ; \square$, SR of propionate;, concentration of glucose; $\mathbf{R}$ concentration of propionate; $\mathbf{A}$, concentration of acetate; concentration of total VFA. The SR of metabolite was standardized to an infusion rate of I $\mu \mathrm{Ci}$ isotope/min. Sodium propionate was infused between the 490 th and 790 th min (horizontal bar) of the isotope infusions.

which $\left[6-{ }^{3} \mathrm{H}\right]$ glucose was infused simultaneously with $\mathrm{NaH}^{14} \mathrm{CO}_{3}$ or with intraruminal infusions of $\left[2^{14} \mathrm{C}\right]$ propionate are given in Figs $\mathrm{I}$ and 2 respectively.

In general, the approximately constant SR of plasma glucose obtained with an infusion of labelled glucose decreased in response to a propionate infusion, and plateaued $1 \cdot 5-3 \mathrm{~h}$ later. The changes in the SR of glucose, which were more rapid with an intravenous than with an intraruminal infusion of propionate (compare Figs I and 2), indicate an increased rate of glucose synthesis. The increment in the irre- 


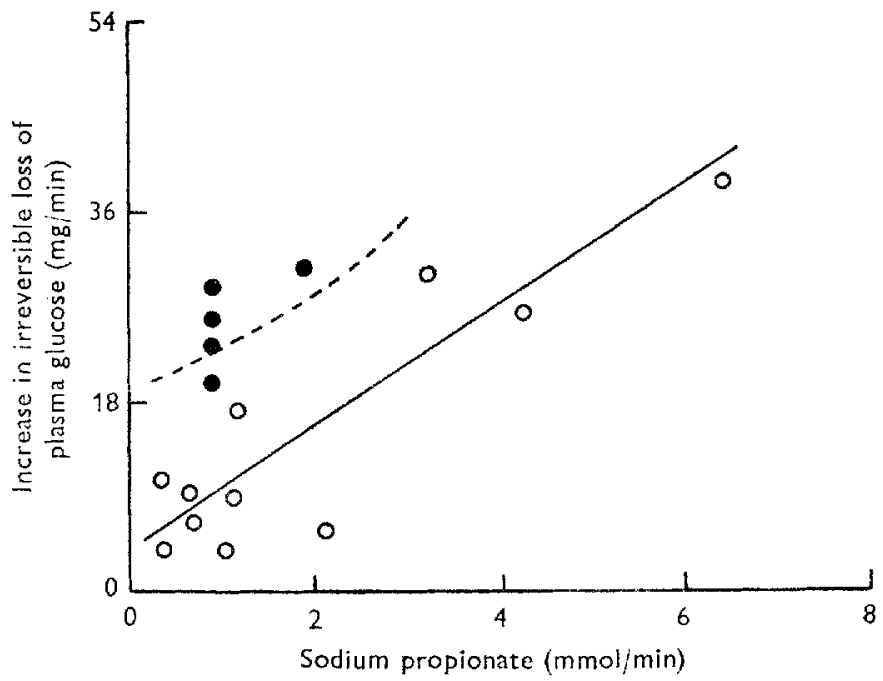

Fig. 3. Relationship between the increment in the irreversible loss of plasma glucose and rate of infusions of sodium propionate into the rumen $(O)$ or into a mesenteric vein $(\bullet)$ in sheep. The regression equation and portion of the $95 \%$ confidence limit for individual observations relating these measurements in sheep given intraruminal infusions of propionate are indicated by unbroken and broken lines respectively.

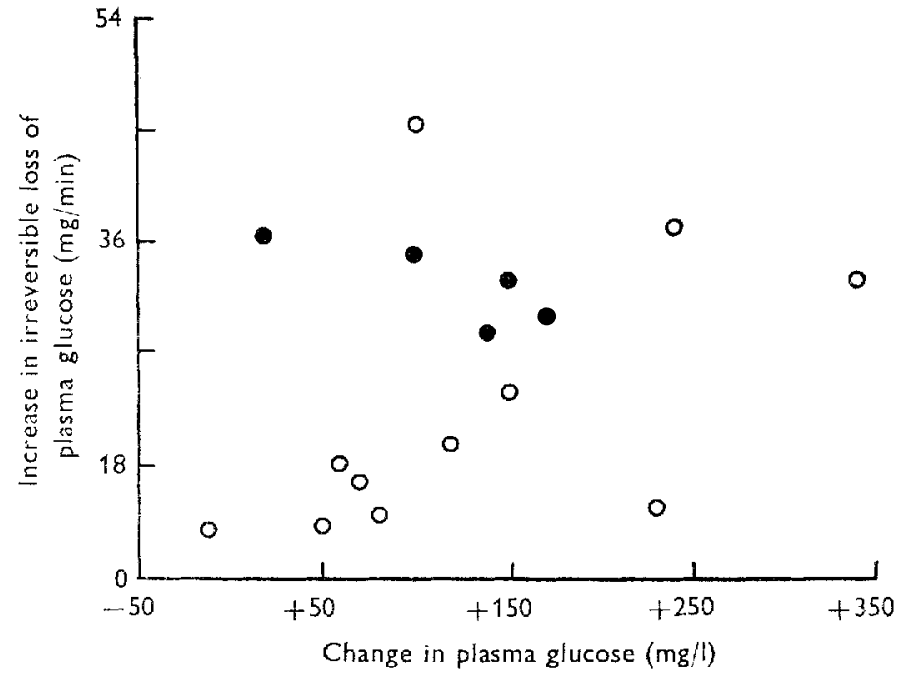

Fig. 4. Relationship between the increment in the irreversible loss of plasma glucose and the change in plasma glucose concentrations in sheep in response to sodium propionate, infused into the rumen $(O)$ or into a mesenteric vein $(\bullet)$.

versible loss of plasma glucose $\left(Y_{I}, \mathrm{mg} / \mathrm{min}\right)$ was linearly related $(P<0.00 \mathrm{I})$ to the quantity of propionate infused intraruminally $\left(X_{P}, \mathrm{mmol} / \mathrm{min}\right)$ and was described by the equation:

$$
Y_{I}=3 \cdot 82+5.97 X_{P}[\mathrm{SE} \text { of slope }= \pm 0.882 ; \mathrm{RSD}= \pm 5 \cdot 13] .
$$

These results are given in Fig. 3. The broken line on Fig. 3 is a confidence interval 

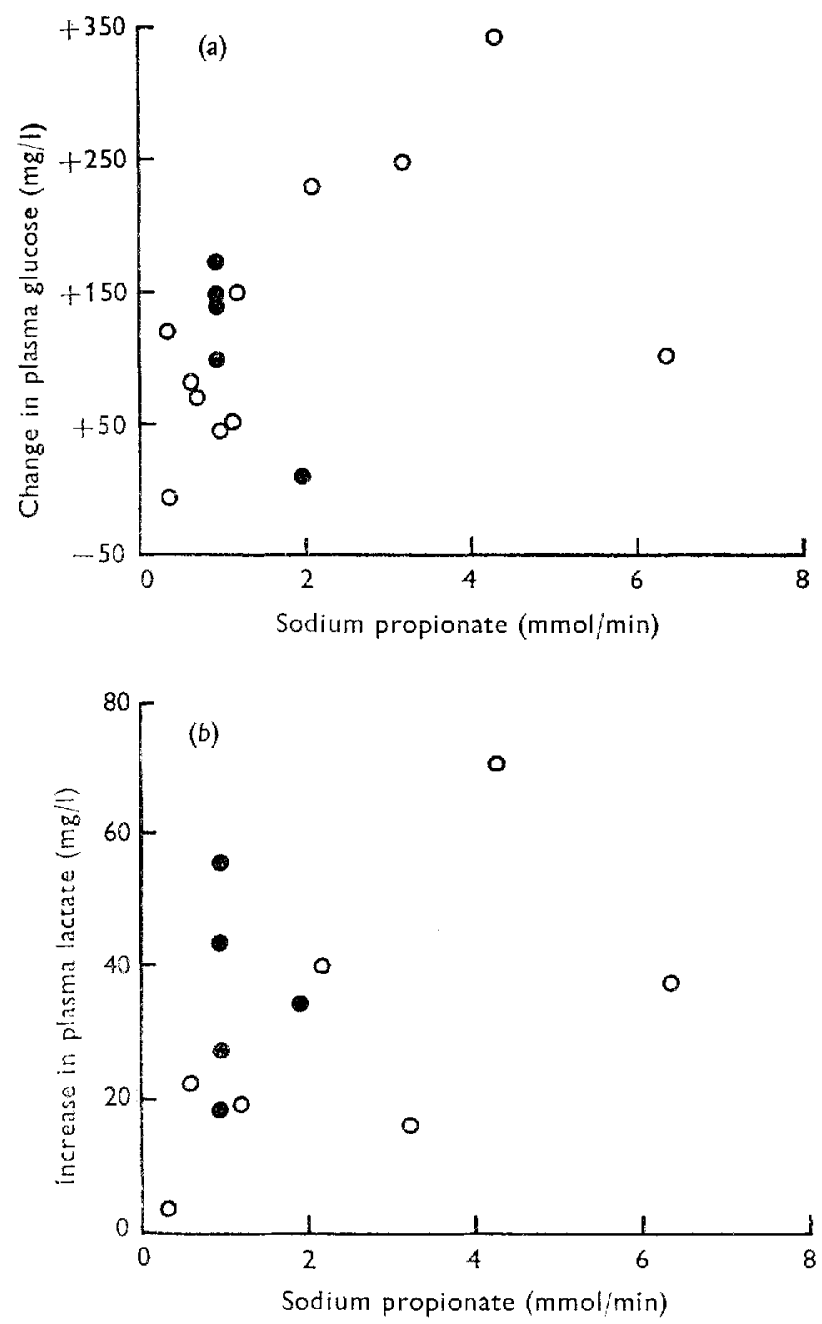

Fig. 5. Relationships between the changes in plasma concentration of glucose $(a)$ or lactate (b) and rate of infusion of sodium propionate into the rumen $(O)$ or into a mesenteric vein (C) of sheep.

beneath which $95 \%$ of observations would be expected to lie. Four out of five results for intravenous infusions were above the line, which suggests that intravenous infusions of propionate elicit a greater response in the irreversible loss of glucose than intraruminal infusions of propionate.

Estimates of the irreversible loss of glucose immediately before and during successive $3 \mathrm{~h}$ infusions of sodium chloride into the mescnteric vein of a sheep at 0.99 and $\mathrm{I} .99 \mathrm{mmol} / \mathrm{min}$ were 86,83 and $80 \mathrm{mg} / \mathrm{min}$ respectively; corresponding mean values for plasma glucose concentrations were not significantly different $(P>0.05)$ from each other.

Plasma glucose concentration usually increased in response to an infusion of propionate to attain an approximately constant level some $\mathbf{I}-3 \mathrm{~h}$ later. 'The change 
Table r. Molar proportions of individual volatile fatty acids (VFA) in jugular blood of sheep before and during intraruminal or intravenous (through a mesenteric vein) infusions of sodium propionate

\begin{tabular}{|c|c|c|c|c|c|c|}
\hline \multirow{2}{*}{$\begin{array}{l}\text { Sheep } \\
\text { no. }\end{array}$} & \multirow{2}{*}{$\begin{array}{l}\text { Sheep wt } \\
\text { (kg) }\end{array}$} & \multirow{2}{*}{$\begin{array}{l}\text { Propionate } \\
\text { infusion } \\
\text { (mmol/min) }\end{array}$} & \multicolumn{4}{|c|}{ Molar percentage of VFA as: } \\
\hline & & & Acetic & Propionic & Butyric & Other: \\
\hline \multirow[t]{2}{*}{$I_{4} \mathrm{O}$} & \multirow[t]{2}{*}{$32 \cdot 7$} & - & $90 \% 4$ & $2 \cdot 6$ & $\mathrm{r} \cdot \overline{7}$ & $5 \cdot 3$ \\
\hline & & $0.99^{*}$ & 72.9 & $2 I \cdot 4$ & $2 \cdot 3$ & $3 \cdot 3$ \\
\hline \multirow[t]{2}{*}{ I 30} & \multirow[t]{2}{*}{$32 \cdot 4$} & - & $94^{-2}$ & $5 \cdot 9$ & nd & nd \\
\hline & & $1 \cdot 92^{*}$ & $56 \cdot 1$ & $43 \cdot 9$ & nd & nd \\
\hline \multirow[t]{2}{*}{114} & \multirow[t]{2}{*}{$34^{*} \pi$} & - & $97 \cdot 8$ & $2 \cdot 2$ & nd & nd \\
\hline & & $0.62+$ & $96 \cdot 6$ & $3 \cdot 4$ & nd & nd \\
\hline \multirow[t]{2}{*}{175} & \multirow[t]{2}{*}{$3 I \cdot I$} & 一 & $82 \cdot 2$ & $6 \cdot 7$ & $4-8$ & $6 \cdot 4$ \\
\hline & & $1 \cdot 12 \dagger$ & 80.9 & 13.5 & $2 \cdot I$ & $3 \cdot 5$ \\
\hline \multicolumn{7}{|c|}{$\begin{array}{l}\text { nd, not determined. } \\
* \text { Intravenous infusions. } \\
+ \text { Intraruminal infusions. }\end{array}$} \\
\hline
\end{tabular}

in the mean concentration of plasma glucose was not corrclated $(P>0.05)$ with the marked increase in the irreversible loss of plasma glucose (see Fig. 4) or with the rate of infusion of propionate (Fig. 5). Plasma lactate concentrations also generally increased during an irfusion of propionate to attain approximately constant values about $2 \mathrm{~h}$ after the start of the infusion (see Fig. I). Fig. 5 shows the non-significant $(P>0.05)$ relationship between the changes in the mean concentration of plasma lactate and propionate infusions.

The molar proportion of propionate in VFA isolated from peripheral blood also increased as the propionate increased (Table $\mathrm{I}$ ). Urea concentrations in plasma were significantly depressed $(P<0.01)$ with intravenous infusions of propionate at $0.99 \mathrm{~m}$ $\mathrm{mol} / \mathrm{min}$. Mean concentrations for three samples taken immediately before and between the 3 rd and the 6 th hour of a propionate infusion were respectively 52 and 47 for sheep 140 , and $5^{1}$ and 42 for sheep 143 .

\section{Effect of propionate infusions on the fixation of blood bicarbonate into glucose}

Since only two reactions, catalysed by propionyl-CoA carboxylase and pyruvate carboxylase, fix bicarbonate carbon into glucose precursors, the total incorporation of carbon- $\mathrm{I}_{4}$ into glucose during constant infusions of $\mathrm{NaH}^{14} \mathrm{CO}_{3}$ is an indication of the extent of gluconeogenesis through these two pathways.

Mixtures of $\mathrm{NaH}^{14} \mathrm{CO}_{3}$ and $\left[{ }^{-}{ }^{3} \mathrm{H}\right]$ glucose were infused intravenously, and the carbon- 14 fixed into glucose and the irreversible loss of glucose were measured before and during intravenous infusions of propionate (see Fig. I). The plateau SR of blood bicarbonate attained during the pre-infusion period was maintained during infusions of propionate but the SR of glucose carbon increased to a plateau $2-3 \mathrm{~h}$ later. The mean values for the plateau SR of glucose before and during the propionate infusion were significantly different $(P<0.05)$, indicating a small increase in the proportion of glucose carbon entering through bicarbonate fixation reactions (Table 2). 


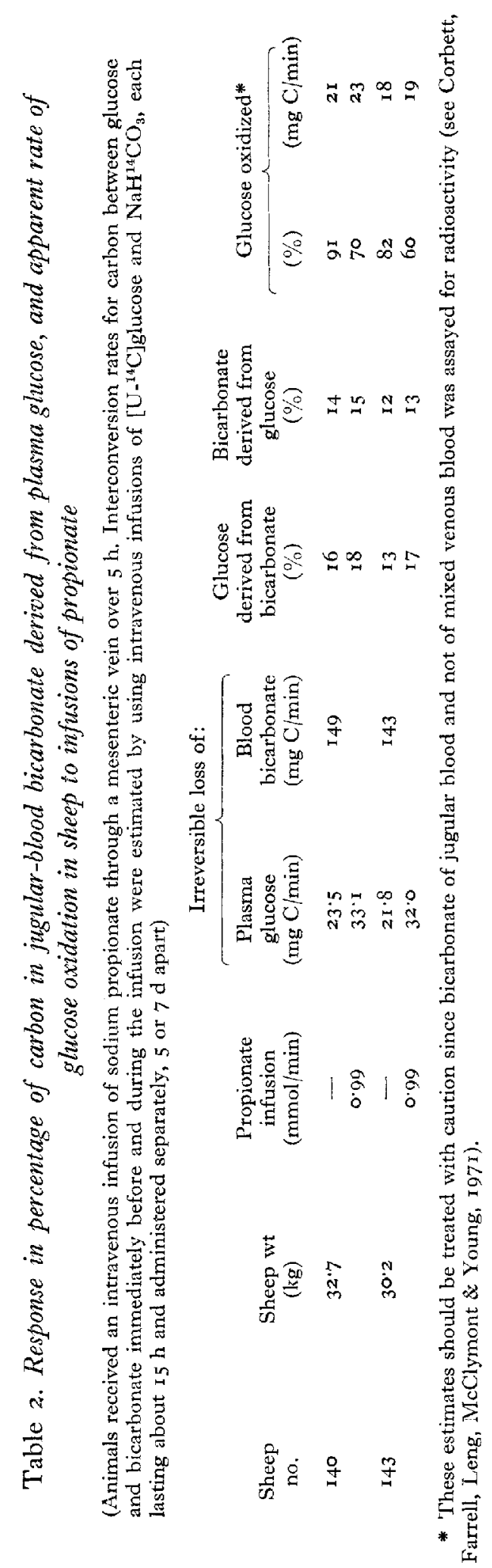


Table 2 also includes estimates of glucose oxidized before and during propionate infusions. These estimates were calculated according to the procedure of Depocas \& De Freitas (1970) for a two-pool model - in this study, the plasma glucose and blood bicarbonate pools. The proportion of blood bicarbonate originating from glucose was determined by comparing the plateau SR values of carbon of bicarbonate

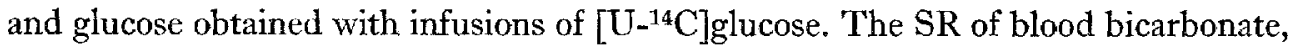
which plateaued from about $7 \mathrm{~h}$ after the start of an infusion of $\left[\mathrm{U}^{14} \mathrm{C}\right]$ glucose, decreased for about the first $3 \mathrm{~h}$ of the propionate infusion before attaining a plateau value. The proportion of plasma glucose oxidized apparently decreased furing infusions of sodium propionate but the apparent rate of glucose oxidation was not altered $(P>0.05)$ since there was an increase in the irreversible loss of plasma glucose.

\section{Effect of propionate on glucose synthesis from propionate}

Intraruminal infusions of sodium propionate resulted in an increase in the measured production rate of propionate in the rumen (see example in Fig. 2) but the increment was less than the rate of addition of propionate (see Table 4). This increment in propionate production rate, expressed as a percentage of the rate of infusion of propionate, was uncorrclated with the rate of infusion $(P>0.05)$ and its mean value was $65 \pm 6 \cdot 4 \%$.

The proportion of propionate in total VFA and the concentration of propionate in ruminal fluid also increased in response to propionate infusions (Table 3). The concentrations of the VFA usually became approximately constant about $2 \mathrm{~h}$ after the start of the propionate infusion. The decreased proportion of other VFA was usually associated with a decrease in the concentration of these acids in ruminal fluid (sce also Fig. 2). The production rate of propionate $\left(Y_{P}, \mathrm{mmol} / \mathrm{min}\right.$ ) during intraruminal infusions of sodium propionate was linearly related $(P<0.001)$ to the concentration of ruminal propionate $\left(X_{C}, \mathrm{mmol} / \mathrm{l}\right)$. The relationship between $Y_{P}$ and $X_{C}$ was:

$$
Y_{P}=-0.242+0.0321 X_{C}(n=8) \text { [sE of slope }= \pm 0.00619 ; \mathrm{RSD}= \pm 0.854 \text { ], }
$$

where $n$ is the number of experiments. The regression coefficient for propionate concentration was similar to the value of 0.0344 derived by Leng (1970b) for the regression coefficient relating these variables in sheep on a wide variety of diets.

The effect of infusion of propionate into the rumen on the net rate of glucose synthesis from ruminal propionate was studied by using, simultaneously, an intravenous infusion of $\left[{ }^{6}{ }^{3} \mathrm{H}\right]$ glucose and an intraruminal infusion of $\left[2-^{14} \mathrm{C}\right]$ propionate (Fig. 2). Results obtained with this technique were not significantly different $(P>0.05)$ from those values determined with the experimental procedures reported previously (see Judson \& Leng, 1968 ), where $\left[2{ }^{14} \mathrm{C}\right]$ propionate and $\left[\mathrm{U}-{ }^{14} \mathrm{C}\right]$ glucose were administered to sheep on separate occasions (Table 4). The relatively constant SR of carbon of ruminal propionate and plasma glucose decreased in response to infusions of propionate to almost a constant value about $2 \mathrm{~h}$ later; occasionally the SR of plasma glucose carbon decreased slowly throughout the infusion of propionate and these results were not considered for estimation of glucose synthesis from pro- 


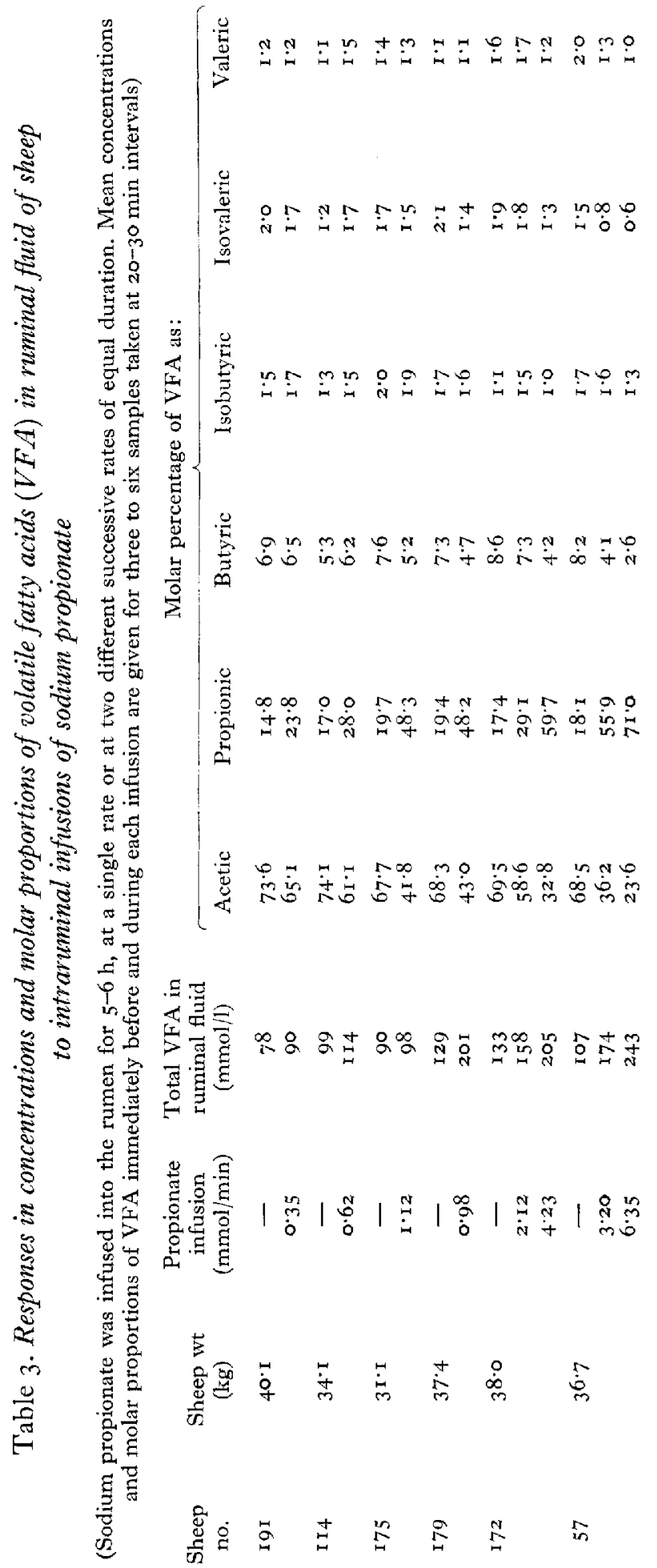




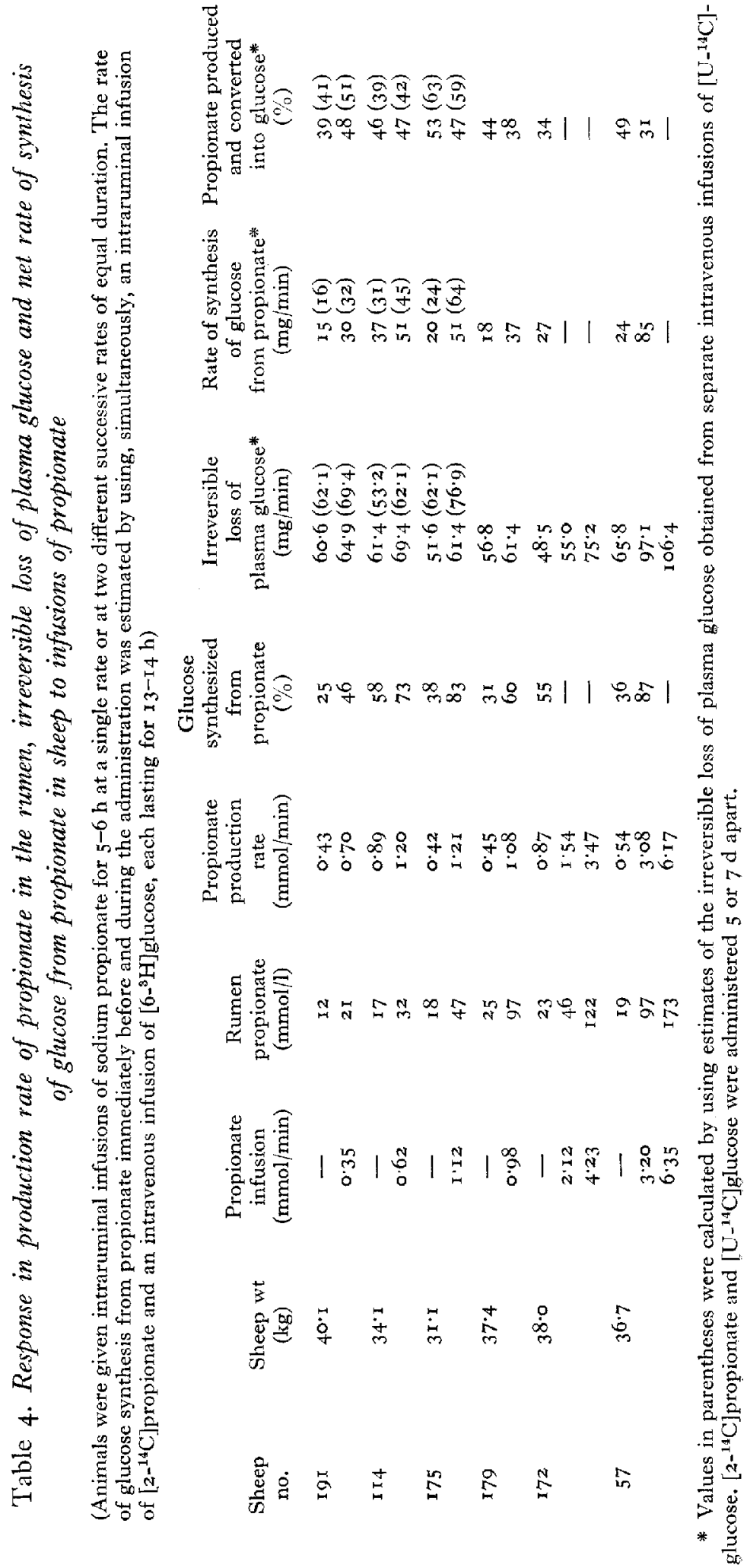



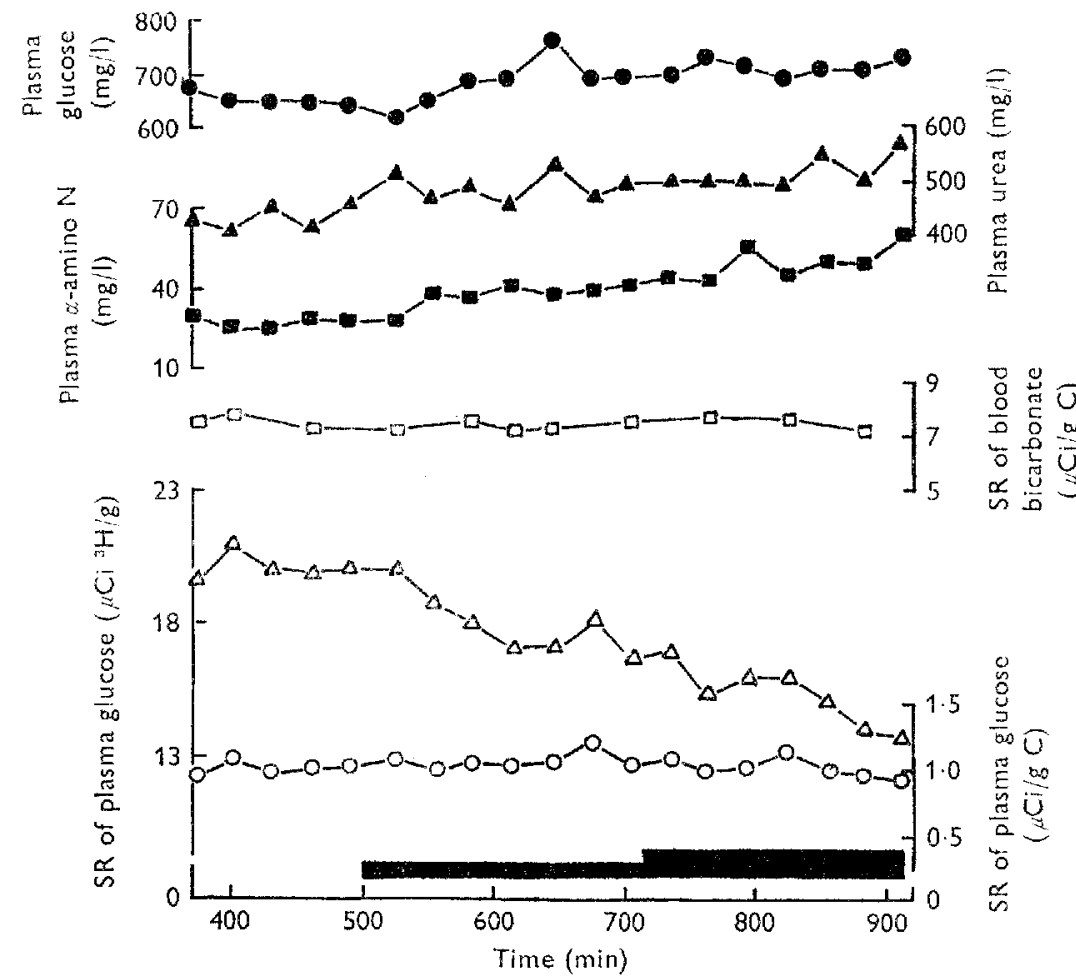

Fig. 6. Effect of successive abomasal infusions of casein hydrolysate on the specific radioactivity (SR) values of plasma glucose and blood bicarbonate, and plasma concentrations of glucose, urea and $\alpha$-amino nitrogen in sheep no. 722 during a constant infusion of a mixture of $\left[6-{ }^{3} \mathrm{H}\right]-$ glucose and $\mathrm{NaH}^{14} \mathrm{CO}_{3} .0$, SR of glucose $(\mu \mathrm{Ci} / \mathrm{g} \mathrm{C}) ; \triangle$, SR of glucose $\left(\mu \mathrm{Ci}{ }^{3} \mathrm{H} / \mathrm{g}\right) ; \square$, SR of blood bicarbonate; concentration of glucose; $\mathbf{R}$, concentration of $\alpha$-amino $\mathrm{N}$; $\mathbf{A}$, concentration of urea. The SR of metabolite was adjusted to an infusion rate of $\mathrm{I} \mu \mathrm{Ci}$ isotope/min. The infusion rates of casein hydrolysate between the 50oth and 730th min and the 730 th and 9 roth $\mathrm{min}$ (horizontal bars) of the infusion of isotopes were 77.7 and $158.6 \mathrm{mg} / \mathrm{min}$ respectively.

pionate. Comparison of the plateau SR values of carbon of ruminal propionate and plasma glucose shows that the proportion of glucose synthesized from propionate increased in response to propionate infusions (Table 4).

\section{Effect of infusions of a mixture of amino acids on glucose synthesis}

Responses in the irreversible loss of plasma glucose and in the fixation of carbon into glucose from blood bicarbonate to intra-abomasal infusions of enzymic-hydrolysed casein were measured in two sheep by using intravenous infusions of a mixture of $\left[6-{ }^{3} \mathrm{H}\right]$ glucose and $\mathrm{NaH}^{14} \mathrm{CO}_{3}$, lasting about ${ }_{5} \mathrm{~h}$. The casein, varying between 57 and $159 \mathrm{mg}$ of total amino acids/min, was administered during the last $7 \mathrm{~h}$ of this infusion of isotopes at two different successive rates of equal duration. An example of the results obtained is given in Fig. 6 .

In general, the concentrations of glucose, urea and $\alpha$-amino nitrogen in plasma increased but varied only slightly after each infusion of casein hydrolysate had been in progress for about $\mathrm{I}^{5} 5^{-2} \mathrm{~h}$. The approximately constant SR of plasma glucose, 
Vol. 29

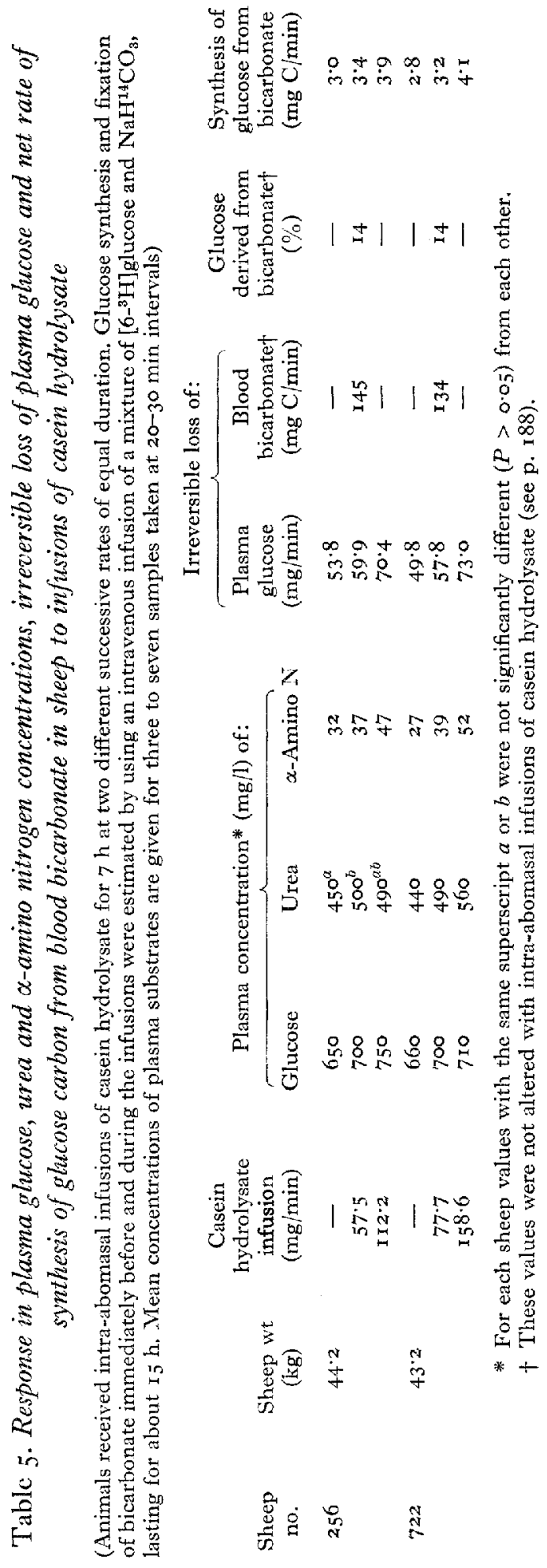


labelled with $\left[6-{ }^{3} \mathrm{H}\right]$ glucose, decreased in response to infusions of casein. However, the SR of glucose was again steady about $2 \mathrm{~h}$ after the start of each infusion except for sheep no. 722 in which the SR continued to decline during the infusion of $158.6 \mathrm{mg}$ casein/min. It was assumed for this infusion rate of casein that a plateau SR was attained after the 3 rd hour of the infusion (see Fig. 6). The approximately constant $\mathrm{SR}$ values of carbon of plasma glucose and blood bicarbonate, labelled with $\mathrm{NaH}^{14} \mathrm{CO}_{3}$, were not altered by infusing casein. A summary of the results appears in Table 5 .

The increment in the irreversible lass of plasma glucose $\left(Y_{I}, \mathrm{mg} / \mathrm{min}\right)$ was linearly related $(P<0.00 \mathrm{I})$ to the rate of infusion of casein hydrolysate $\left(X_{A}, \mathrm{mg} / \mathrm{min}\right)$. The relationship between $Y_{I}$ and $X_{A}$ was:

$$
Y_{I}=-4 \cdot 55+0 \cdot 178 X_{A}(n=4)[\mathrm{SE}= \pm 0.017 \mathrm{I} ; \mathrm{RSD}= \pm \mathrm{I} \cdot 3 \mathrm{I}] .
$$

\section{Effect of infusions of butyrate on glucose synthesis from propionate}

Two sheep were given, simultaneously, an intravenous infusion of $\left[6-{ }^{3} \mathrm{H}\right]$ glucose and an intraruminal infusion of $\left[2-{ }^{14} \mathrm{C}\right]$ propionate, lasting about $14 \mathrm{~h}$. Sodium butyrate was infused into a mesenteric vein during the last $6 \mathrm{~h}$ of the tracer infusions at $0.25 \mathrm{mmol} / \mathrm{min}$ for $3 \mathrm{~h}$ and increased to $0.50 \mathrm{mmol} / \mathrm{min}$ for a further $3 \mathrm{~h}$. Responses in the SR and concentration of plasma glucose to butyrate in each sheep were similar and the mean results are shown in Fig. 7. A transient increase in plasma glucose concentration concomitant with a decrease in the SR of glucose occurred immediately after the start of the butyrate infusion. These values returned to approximate pre-infusion values within $2 \mathrm{~h}$ and were not altered by the additional infusion of butyrate.

The irreversible loss of plasma glucose and the net rate of synthesis of glucose from propionate are given in Table 6 and were calculated from a consideration of the plateau SR values of glucose immediately before and during the butyrate infusion. Estimates of glucose synthesis from propionate during the transient increase in plasma glucose concentrations, calculated by using the SR values associated with the maximum response recorded in glucose concentration, are included in Table 6 . These calculations indicate that although the proportion of plasma glucose derived from ruminal propionate decreased markedly during the transient change in glucose production, the net rate of glucose synthesis from propionate was altered only slightly.

Mean concentrations of $\beta$-hydroxybutyrate and urea in plasma before and during infusions of butyrate are given in Table 6. In general, the concentrations of $\beta$ hydroxybutyrate and urea increased and decreased respectively in response to butyrate but these changes were usually not significant $(P>0.05)$. The molar proportion of butyrate in VFA in jugular blood increased with infusions of butyrate. These changes were similar for the two sheep and the mean molar percentages immediately before and during butyrate infusions at 0.25 and $0.50 \mathrm{mmol} / \mathrm{min}$ were respectively $96 \cdot 0,94 \cdot 5$ and $92 \cdot 8$ for acetate, $3.3,3.3$ and 3.4 for propionate, and $0.7,2 \cdot 2$ and $3 \cdot 8$ for butyrate. 


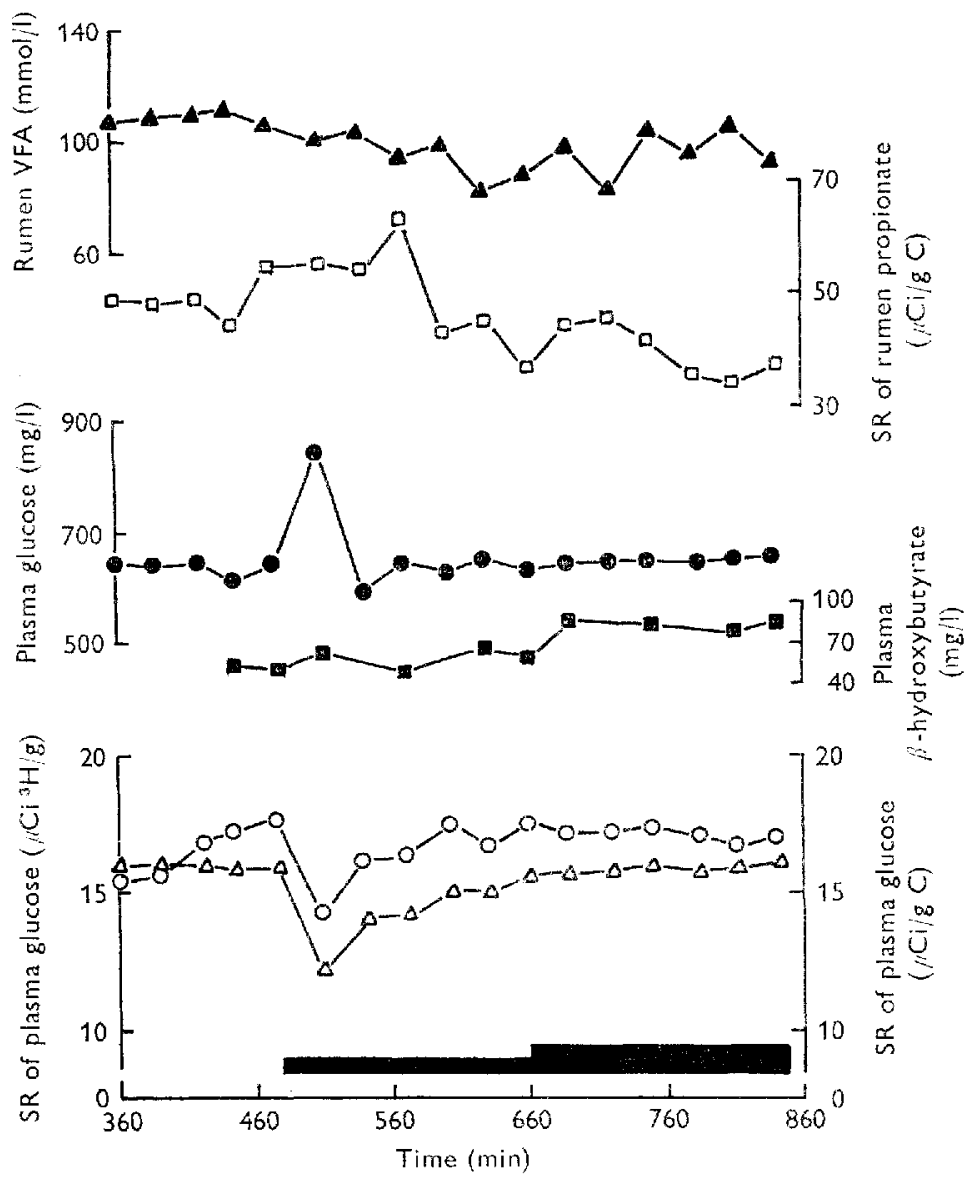

Fig. 7. Effect of successive intravenous infusions of sodium butyrate on the specific radioactivity (SR) values of plasma glucose, and plasma concentrations of glucose and $\beta$-hydroxybutyrate during an intravenous infusion of $\left[6-{ }^{3} \mathrm{H}\right]$ glucose and an intraruminal infusion of $\left[2-{ }^{14} \mathrm{C}\right]$ propionate, administered simultaneously. The results are the means for sheep no. $\mathrm{I}_{3} \mathrm{O}$ and $183 . O, \mathrm{SR}$ of glucose $(\mu \mathrm{Ci} / \mathrm{g} \mathrm{C}) ; \triangle$, SR of glucose $(\mu \mathrm{Ci} \mathbf{H} / \mathrm{g}) ; \square$, SR of ruminal propionate; concentration of glucose; $\boldsymbol{B}$, concentration of $\beta$-hydroxybutyrate; $\boldsymbol{\Lambda}$, concentration of total VFA in ruminal fluid. The SR of metabolite was adjusted to an infusion rate of $\pi \mu \mathrm{Ci}$ isotope $/ \mathrm{min}$. The infusion rates of butyrate from the 480 th to 660 th $\mathrm{min}$ and the 660 th to 840 th $\mathrm{min}$ (horizontal bars) of the isotope infusions were 0.25 and $0.50 \mathrm{mmol} / \mathrm{min} \mathrm{respec}$ tively.

\section{DISCUSSION}

\section{Effect of propionate on gluconeogenesis}

We have demonstrated that an increased availability of propionate in sheep given a lucerne diet stimulated an increase in the irreversible loss of plasma glucose and that this increase appeared to be dependent on the quantity of propionate infused. The response in glucose production to intraruminal infusions of propionate was due to an increase in synthesis of glucose from ruminal propionate. Similarly, the marked increase in the rate of fixation of carbon from blood bicarbonate into plasma glucose when propionate was infused into the mesenteric vein suggests an increased rate of 
gluconeogenesis. The extra glucose was probably synthesized from infused propionate since intraportal infusions of sodium propionate have been shown to increase the proportion of plasma glucose derived from propionate in fed sheep (Bergman, Roe \& Kon, 1966). The apparently greater response in gluconeogenesis to intravenous than to intraruminal infusions of propionate (see Fig. 3) may have been due to the accumulation of sodium propionate in the rumen inhibiting microbial production of propionate. The procedure used in this study for measuring the propionate produced in the rumen is unlikely to result in appreciable error (see Leng, 1970 b) and it seems likely that the consistently lower increment in rate of production of propionate compared with the rate of addition of propionate to the rumen was real. There is evidence that rate of growth of ruminal micro-organisms increases upon dilution (El-Shazly \& Hungate, 1965; Hobson, 1965; Hobson \& Summers, 1967), which may indicate a possible inhibitory effect of end-products of microbial metabolism (Walker \& Forrest, quoted by Walker, I965).

Propionate absorbed from the rumen of the sheep is largely removed from portal blood in its passage through the liver (Annison, Hill \& Lewis, 1957; Cook \& Miller, 1965; Bergman \& Wolff, 1971). The capacity of the liver or other tissues to remove propionate, however, was apparently exceeded in the present study, when propionate was infused into either the rumen or mesenteric vein. Smith \& Marston (197I) calculated from in vitro studies that the maximum rate of utilization of propionate by liver of a $30 \mathrm{~kg}$ sheep was about $0.5 \mathrm{mmol} / \mathrm{min}$, equivalent to the synthesis of approximately $45 \mathrm{mg}$ glucose/min if all the propionate was converted into glucose. This estimate of glucose synthesis from propionate is only about half the recorded maximum production of glucose from ruminal propionate in our study (see Table 4). In the intact animal, the conversion of propionate into glucose or into other glucogenic precursors may have occurred also in tissues other than liver.

Krebs \& Yoshida (1963), and Weidermann \& Krebs (1969) have shown that kidney cortex slices from sheep readily form glucose from propionate. However, the contribution of this organ to total glucose synthesis in the intact sheep appears to be quantitatively insignificant (Kaufman \& Bergman, 197x), but this may not be so when circulating levels of propionate or lactate are raised by infusions of propionate.

Rates of production of lactate may have increased with propionate infusions, as indicated by the increased concentrations of plasma lactate (Annison, Lindsay \& White, x963). In support of this suggestion Leng, Steel \& Luick (1967) reported that as much as $70 \%$ of the ruminal propionate converted into glucose in fed sheep first formed lactate and Annison, Leng, Lindsay \& White (1963) showed that intraportal infusions of substantial quantities of $\left[{ }^{14} \mathrm{C}\right]$ propionate into anaesthetized sheep also led to the labelling of lactate. It is possible that much of this lactate was produced from propionate by extrahepatic tissue such as ruminal epithelium (see Pennington \& Sutherland, 1956; Taylor \& Ramsay, 1965) and that its subsequent conversion into glucose by liver or kidney tissue provided a significant proportion of the glucose synthesized during propionate infusions.

Lactate, however, may also have been produced from propionate in liver (Leng $\$$ Annison, 1963) and from the resulting increase in glucose utilization during pro- 
pionate infusions, although the latter pathway was probably not of importance since Judson \& Leng (1973) found little or no increase in plasma lactate in fed sheep given intravenous infusions of glucose. Unlike ruminal epithelium (Young, Thorp \& De Lumen, I 969), sheep liver contains little or no detectable NADP-malate dehydrogenase activity (see Ballard, Hanson \& Kronfeld, 1969). Any synthesis of lactate from propionate in liver probably occurs by the oxidation of succinate to oxaloacetate and the conversion of the latter into phosphoenolpyruvate before the synthesis of pyruvate and lactate. Extensive conversion of propionate into lactate in liver during propionate infusions could indicate that the activity of pyruvate kinase or the activity of enzyme(s) distal to phosphoenolpyruvate in the gluconeogenic pathway were limiting glucose synthesis.

Most of the glucogenic intermediates in ruminants enter the tricarboxylic acid cycle before they are oxidized or converted into glucose (see Black, Egan, Anand \& Chapman, 1968; Leng, 1970a). The apparent suppression of the contribution of substrates other than propionate to glucose synthesis during intraruminal infusions of propionate (Table 4) was probably largely due to their dilution in the tricarboxylic acid cycle of the hepatic cell by propionate (and lactate or other glucogenic precursors arising from propionate metabolism in extrahepatic tissue), particularly as the percentage of propionate absorbed from the rumen and converted into glucose was not markedly altered but provided a greater proportion of the glucose synthesized. A possible increase in protein synthesis or decrease in protein catabolism with VFA infusions, as indicated by a diminution in the plasma concentration of urea (present study) and amino acids (Potter, Purser \& Cline, 1968; Halfpenny, Rook \& Smith, I969) is unlikely to result in any marked reduction in the availability of amino acids for gluconeogenesis since with butyrate infusions glucose synthesis from propionate or other precursors was not altered.

\section{Effect of amino acids on gluconeogenesis}

Amino acid carbon is believed to be a main source of glucose carbon in ruminants. Because of the large number of glucogenic amino acids the measurement of the proportion of plasma glucose derived from amino acids in the intact animal is difficult, particularly as the SR of the circulating amino acids may not be representative of those amino acids converted into glucose (see Reilly \& Ford, 1971). In our study a constant infusion of $\mathrm{NaH}^{14} \mathrm{CO}_{3}$ was administered intravenously with $\left[6-{ }^{3} \mathrm{H}\right]$ glucose to determine the rate and indicate the source of substrate for glucose synthesis in sheep given intra-abomasal infusions of enzymic-hydrolysed casein.

The quantity of hydrolysate infused into the abomasum was positively correlated with the increase in irreversible loss of plasma glucose. The contribution of amino acids to glucose synthesis may have increased as indicated by the raised levels of $\alpha$ amino nitrogen and urea in plasma. It is unlikely that any amino acids from the casein hydrolysate reached the large intestine since casein placed into the abomasum of sheep at comparable rates is completely digested and absorbed (Reis \& Schinckel, I961; Blaxter \& Martin, 1962). Reilly \& Ford (1971) showed that the rate of con- 
version of amino acids into glucose was linearly related to the production rate of plasma amino acids.

Although only two animals have been examined it appears from a consideration of equation 3 that for every $100 \mathrm{~g}$ casein hydrolysate administered to sheep approximately $13 \mathrm{~g}$ of extra plasma glucose were synthesized. This is considerably less than the theoretical maximum of about $57 \mathrm{~g}$ glucose if all the gluconeogenic amino acids were deaminated and converted into glucose (Krebs, 1964). Lindsay \& Williams (1971) reported an increased production of glucose of $27-60 \mathrm{~g} / \mathrm{d}$ in fed sheep when given an intra-abomasal infusion of $100 \mathrm{~g}$ casein daily for $3 \mathrm{~d}$. The increase in glucose production, however, need not indicate the quantity of glucose derived from the infused substrate as discussed earlier for intraruminal infusion of $\left[{ }^{4} \mathrm{C}\right]$ propionate. If infused amino acids did contribute substantially to glucose synthesis in our study, it is of interest to note that the proportion of glucose carbon derived from blood bicarbonate was not altered. Casein is composed of a high proportion of glucogenic amino acids which do not require a carboxylation step for their conversion into glucose.

\section{Effect of butyrate on gluconeogenesis}

Black, Luick, Moller \& Anand (1966) and Leng (1970a) have proposed that butyrate may be an important modulator of gluconeogenesis in ruminants since butyrate absorbed from the rumen is metabolized preferentially by ruminal epithelium and liver and provides a source of acetyl-CoA or butyryl-CoA which can activate pyruvate carboxylase (Keech \& Utter, 1963 ; Wallace \& Utter, quoted by Ballard $e t$ al. r 969 ).

Many studies, including those of Jarrett, Potter \& Filsell (1952), Ash, Pennington \& Reid (1964) and Phillips, Black \& Moller (1965) have shown that injections of butyrate produce a hyperglycaemic response in ruminants. In the present study the transient increase in plasma glucose concentration initiated by intramesenteric vein infusions of small quantities of sodium butyrate $(0.25 \mathrm{mmol} / \mathrm{min})$ was not associated with any change in the net rate of conversion of ruminal propionate to plasma glucose. Further, it is unlikely that this transient increase in glucose production was due to the stimulation of pyruvate carboxylase activity since plasma lactate is labelled extensively during intraruminal infusions of $\left[2^{-14} \mathrm{C}\right]$ propionate (Leng et al. ${ }^{1967}$ ).

The most probable explanation for the transient increase in the rate of glucose production in sheep was the mobilization of liver glycogen. Phillips et al. (I965) have reported that an increased phosphorylase activity in the liver of lambs given injections of sodium butyrate was associated with the hyperglycaemia. This effect of butyrate is believed to be mediated by increased secretions of glucagon (Phillips, House, Miller, Mott \& Sooby, 1969). In the present study infused butyrate entered the general circulation and could have stimulated glucagon secretion by the pancreas (Phillips \& Black, I966; Manns, r969).

The increases in the concentration and production of plasma glucose obtained with infusions of propionate, amino acids or butyrate were usually of sufficient magnitude to suppress glucose synthesis in fed sheep (see Judson \& Leng, 1973). Judson \& Leng (1973) suggested that this inhibitory effect of plasma glucose on gluconeogenesis was 
probably largely mediated through an increase in insulin secretion. Propionate and butyrate also stimulate insulin secretion in ruminants (Manns \& Boda, I967; Manns, Boda \& Willes, 1967; Horino, Machlin, Hertelendy \& Kipnis, I968) and there is some evidence that the absorption of amino acids from the alimentary tract may initiate insulin release in sheep (Bassett, Weston \& Hogan, I97I). However, associated increases in glucagon secretion were also possible with infusions of propionate (Manns et al. 1967; Manns, 1969; Bassett, I97I) or amino acids (see Ohneda, Parada, Eisentraut \& Unger, I968) which may have antagonized glucose-mediated or insulin effects on glucose synthesis. Antagonistic actions of glucagon and insulin are indicated from studies with rat liver (see Exton, Mallette, Jefferson, Wong, Friedmann, Miller \& Park, 1970) and they are probably best explained by their interaction in the adenyl cyclase system (Exton, Jefferson, Butcher \& Park, 1966).

The maximum rates of glucose synthesis recorded in our study with infusions of propionate or casein hydrolysate were considerably less than those reported for pregnant or lactating sheep (see Leng, x970 a). However, the increased response in glucose synthesis to these infusions were linear, indicating that the maximum capacity of the animal for gluconeogenesis was not attained, especially if these two substrates were additive in stimulating gluconeogenesis. The availability of these substrates may in part account for the differences in the irreversible loss of plasma glucose in sheep given roughage diets of different energy and protein content (Ford, 1965; Judson \& Leng, r968). In accord with this suggestion Katz \& Bergman (r969) reported that hepatic glucose production in sheep was greatest $2-4 \mathrm{~h}$ after feeding, which probably coincided with maximum production of the glucogenic precursors propionate and microbial protein in the rumen (see Gray, Weller, Pilgrim \& Jones, I966).

In conclusion, whenever extra gluconeogenic substrates were given to sheep its rate of synthesis of glucose increased, indicating that the animal has at all times a capacity to synthesize more glucose than it apparently does. Approximately one-third of the substrate added was channelled into glucose. The control of glucose metabolism in ruminants appears to be centred around the availability of glucogenic precursors and the effect these have on hormonal secretions, particularly those of the pancreas.

We gratefully acknowledge financial support from the Australian Wool Research Committee.

\section{REFERENCES}

Annison, E. F., Hill, K. J. \& Lewis, D. (1957). Biochem. F. 66, 592.

Annison, E. F., Leng, R. A., Lindsay, D. B. \& White, R. R. (1963). Biochem. F. 88, 248.

Annison, E. F. \& Lindsay, D. B. (1961). Biochem. F. 78, 777.

Annison, E. F., Lindsay, D. B. \& White, R. R. (1963). Biochem. $\% .88,243$.

Annison, E. F. \& Linzell, J. L. (1964). F. Physiol., Lond. 175, 372.

Annison, E. F. \& White, R. R. (I96I). Biochem. F. 80, I62.

Ash, R. W., Pennington, R. J. \& Reid, R. S. (I964). Biochem. 7. 90, 353.

Ballard, F. J., Hanson, R. W. \& Kronfeld, D. S. (1969). Fedn Proc. Fedn Am. Socs exp. Biol. $28,218$. Bassett, J. M. (197 I). Aust. F. biol. Sci. 24, 3 тx.

Bassett, J. M., Weston, R. H. \& Hogan, J. P. (1971). Aust. J. biol. Sci. 24, 321.

Bergman, E. N. (1963). Am. Y. Physiol. 204, 147. 
Bergman, E. N. \& Hogue, D. E. (1967). Am. F. Physiol. 213, 1378.

Bergman, E. N., Roe, W. E. \& Kon, K. (I966). Am. F. Physiol. 2Ir, 793.

Bergman, E. N. \& Wolff, J. E. (1971). Am. $\mathcal{~ . ~ P h y s i o l . ~ 2 2 1 , ~} 586$.

Black, A. L., Egan, A. R., Anand, R. S. \& Chapman, T. E. (I968). In Isotope Studies on the Nitrogen Chain p. 247. Vienna: I.A.E.A.

Black, A. L., Luick, J., Moller, F. \& Anand, R. S. (rg66). F. biol. Chem. 241, 5233.

Blaxter, K. L. \& Martin, A. K. (I962). Br. J. Nutr. 16, 397.

Cook, R. M. \& Miller, L. D. (1965), f. Dairy Sci. 48, I339.

Corbett, J. L., Farrell, D. J., Leng, R. A., McClymont, G. L. \& Young, B. A. (1971). Br. F. Nutr. 26, 277.

Depocas, F. \& De Freitas, A. S. W. (r970). Can. 7 . Physiol. Pharmac. 48, 557.

El-Shazly, K. \& Hungate, R. E. (1965). Appl. Microbiol. 13, 62.

Exton, J. H., Jefferson, L. S., Butcher, R. W. \& Park, C. R. (I966). Am. F. Med. 40, 709.

Exton, J. H., Mallette, L. E., Jefferson, L. S., Wong, E. H. A., Friedmann, N., Miller, T. B. \& Park, C. R. (1970). Recent Prog. Horm. Res. 26, $4 \mathrm{I}$.

Ford, E. J. H. (1963). Biochem. F. 88, 427 .

Ford, E. J. H. (1965). Y. agric. Sci, Camb. 65, 41.

Gray, F. V., Weller, R. A., Pilgrim, A. F. \& Jones, G. B. (1966). Aust. F. agric. Res. r7, 69.

Halfpenny, A. F, Rook, J. A. F. \& Smith, G. H. (I969). Br. J. Nutr. 23, 547.

Hobson, P. N. (1965). F. gen. Microbiol. $38,167$.

Hobson, P. N. \& Summers, R. (1967). F. gen. Microbiol. 47, 53.

Horino, M., Machlin, L. J., Hertelendy, F. \& Kipnis, D. M. (1968). Endocrinology 83, I 8.

Jarrett, I. G., Potter, B. J. \& Filsell, O. H. (1952). Aust. F. exp. Biol. med. Sci. 30, 197.

Judson, G. J., Anderson, E., Luick, J. R. \& Leng, R. A. (I968). Br. F. Nutr. 22, 69 .

Judson, G. J. \& Leng, R. A. (1968). Proc. Aust. Soc. Anim. Prod. 7, 354.

Judson, G. J. \& Leng, R. A. (1973). Br. \%. Nutr. 29, I59.

Katz, M. L. \& Bergman, E. N. (1969). Am. F. Physiol. 216, 953.

Kaufman, C. F. \& Bergman, E. N. (I971). Am. F. Physiol. 221, 967.

Keech, D. B. \& Utter, M. F. (1963). F. biol. Chem. 238, 2609.

Krebs, H. A. (1964). In Mammalian Protein Metabolism p. 25 [H. N. Munro and J. B. Allison, editors]. New York: Academic Press.

Krebs, H. A. \& Yoshida, T. (1963). Biochem. $\% .89,398$.

Kronfeld, D. S. \& Simesen, M. G. (r96r). Am. F. Physiol. 2or, 639.

Leng, R. A. (1970a). Adv. vet. Sci. 14, 209.

Leng, R. A. (19706). In Physiology of Digestion and Metabolism in the Ruminant p. 406 [A. T. Phillipson, editor]. Newcastle upon Tyne: Oriel Press Ltd.

Leng, R. A. \& Annison, E. F. (1963). Biochem. F. 86, 319.

Leng, R. A., Steel, J. W. \& Luick, J. R. (1967). Biochem. $\mathcal{F}$. ro3, 785 .

Lindsay, D. B. \& Williams, R. L. (r97I). Proc. Nutr. Soc. 3o, 35 A.

Manns, J. G. (1969). Fedn Proc. Fedn Am. Socs exp. Biol, 28, 49 г.

Manns, J. G. \& Boda, J. M. (1967). Am. \%. Physiol. 212, 747.

Manns, J. G., Boda, J. M. \& Willes, R. F. (1967). An. $\%$. Physiol. 212, 756.

Moodie, E. W., Walker, A. I. T. \& Hutton, P. H. (1963). Q. Fl exp. Physiol. 48, 379 .

Ohneda, A., Parada, E., Eisentraut, A. M. \& Unger, R. H. (1968). F. clin. Invest. 47, 2305.

Pennington, R. J. \& Sutherland, 'T. M. (1956). Biochem. $\mathcal{F} .63,6$ r 8.

Phillips, R. W. \& Black, A. L. (1966), Ұ. comp. Biochem. Physiol. 18, 527.

Phillips, R. W., Black, A. L. \& Moller, F. (1965). Life Sciences 4, 521.

Phillips, R. W., House, W. A., Miller, R. A., Mott, J. L. \& Sooby, D. L. (1969). Am. F. Physiol. 217, 1265 .

Potter, E. L., Purser, D. B. \& Cline, J. H. (1968). F. Nutr. 95, 655.

Reilly, P. E. B. \& Ford, E. J. H. (r97r). Br. F. Nutr. 26, 249.

Reis, P. J. \& Schinckel, P. G. (I961). Aust. F. agric. Res. 12, 335 .

Rosen, H. (1957). Archs Biochem. Biophys. 67, 10.

Smith, R. M. \& Marston, H. R. (1971). Br. F. Nutr. 26, 4 I.

Steel, J. W. \& Leng, R. A. (т 968). Proc. Aust. Soc. Anim. Prod. 7, 342.

Taylor, T. A. \& Ramsay, H. A. (I965). F. Dairy Sci. 48, 505.

Walker, D. J. (1965). In Physiology of Digestion in the Ruminant p. 296 [R. W. Dougherty, editor]. Washington, DC: Butterworths.

Weidermann, M. J. \& Krebs, H. A. (1969). Biochem. F. I12, r49.

Williamson, D. H., Mellanby, J. \& Krebs, H. A. (1962). Biochem. J. 82, 90.

Young, J. W., Thorp, S. L. \& De Lumen, H. Z. (1969). Biochen. F. 114, 83. 